\title{
OCCURRENCE OF CRONOBACTER SPECIES IN KAREISH AND DOMIATI CHEESES
}

\author{
NAGAH M. SAAD and WALLAA F. AMIN \\ Dept. of Food Hygiene, Fac. of Vet. Med., Assiut University. \\ Email: wallaa 800@yahoo.com
}

\section{ABSTRACT}

Received at: 19/6/2014

Accepted: 5/7/2014
A total of 100 samples of Domiati and Kareish cheese were randomly collected and examined for the detection of Cronobacter species. Detection was performed using Cronobacter Screening Broth (CSB), Chromogenic Cronobacter Isolation Agar (mDFI) followed by biochemical testing. Cronobacter species were isolated from $8 \%$ of total samples. Cronobacter sakazakii was isolated from both Kareish and Domiati cheeses, while, Cronobacter malonaticus and Cronobacter turicensis were isolated only from Kareish cheese. The identified isolates of Cronobacter sakazakii were further tested by real time PCR. The results indicate that Kareish and Domiati cheeses represent risk for humans and further attention should be paid for manufacturing and handling of such cheeses.

Key words: Cronobacter species, Chromogenic Cronobacter Isolation Agar, Cronobacter sakazakii, cheese

\section{INTRODUCTION}

Cronobacter species are opportunistic Gramnegative pathogens associated with potentially fatal neonatal infections, including meningitis, sepsis and necrotizing enterocolitis (NEC) (Hunter and Bean, 2013). They are considered emerging foodborne pathogens that have drawn attention to the sceintific community for the last 50 years. The organism was first characterized in 1929 as yellow pigmented coliform (Farmer et al., 1980).

It was suspected to be the causative agent of septicemia in infants. Also, in the 1960s, it was suspected to be the cause of neonatal meningitis (Urmenyi and Franklin, 1961 \& Nazarowec-White and Farber, 1997). By the 1980s, this pathogen was classified as a new species, Enterobacter sakazakii, a member of the Enterobacteriaceae family, which was found to cause serious infections as sepsis, necrotic enterocolitis and meningitis in infants and neonates (Farmer et al., 1980).

The bacterium was reclassified into the new genus Cronobacter in 2007 (Iversen et al., 2007). It was validly published in 2008 with 5 species and 3 subspecies (Iversen et al., 2008). Now the genus includes nine species, C. sakazakii, C. malonaticus, C. turicensis, C. muytjensii, C. dublinesis, $C$. universalis and C. condimenti (Joseph et al., 2012).

All Cronobacter spp., except $C$. condimenti have been linked to clinical cases of infection in either adults or infants. The majority of cases occur in adults, most often bacteraemia, in addition to wound infection, abscesses and ulcers (Healy et al., 2010 and Kucerova et al., 2011).

Due to its ubiquitous nature, the primary reservoir for subsequent contamination of food with cronobacters remained unidentified; however, it can be isolated from a wide variety of foods including milk, cheese and dried foods (Friedemann, 2007).

El-Sharoud et al. (2008) isolated the organism from related imitation recombined soft cheese. Moreover, El-Gamal et al. (2013) could isolate this pathogen from Domiati cheese.

Owing to the health hazard associated with Cronobacters, this study aimed to search for its occurance in the most popular soft cheese in Egypt using conventional methods and real time PCR.

\section{MATERIALS and METHODS}

\section{Collection of samples:}

A total of 100 random samples of Domiati and Kareish cheeses (50 samples each) were collected from different localities in Assiut city then transferred to the laboratory to be examined.

The samples were prepared according to A.P.H.A., 2004.

Isolation of Cronobacter species (Iversen et al., 2008)

- Preenrichment of samples

Eleven grams from the prepared cheese sample were transferred to a sterile beaker containing $99 \mathrm{ml}$ of sterile $0.1 \%$ peptone water, then were incubated at $37^{\circ} \mathrm{C}$ for $18 \mathrm{~h}$. 


\section{- Enrichment}

$0.1 \mathrm{ml}$ of the pre-enriched sample was inoculated into a sterile test tube containing $10 \mathrm{ml}$ Cronobacter Screening Broth (CSB) (Oxoid, CM 1121) and then was incubated at $42{ }^{\circ} \mathrm{C}$ for $24 \mathrm{~h}$. Positive result is indicated by color change from purple to yellow.

\section{- Selective plating}

A loopful of the incubated broth was then streaked on the surface of Chromogenic Cronobacter Isolation Agar (mDFI) (modified Druggan, Forsythe and Iversen agar) (Oxoid Ltd., Basingstoke, United Kingdom). The plates were incubated at $44{ }^{\circ} \mathrm{C}$ for 24 h. Typical colonies appear as blue/green which were transferred to Trypticase Soy Agar (TSA) and incubated at $37^{\circ} \mathrm{C}$ for $48 \mathrm{~h}$. Colonies appeared as yellow pigmented.

Identification of the isolated Cronobacter spp. was done according to Iversen et al., 2008 by biochemical testing.

- Identification of the isolated C. sakazakii using TaqMan real time PCR according to Seo and Brackett, 2005.

\section{DNA extraction:}

Strains were cultured on tryptone soy agar (TSA) at $37^{\circ} \mathrm{C}$. DNA was extracted from a single colony by using QIAamp DNA mini kit following the manufacturer's instructions.

\section{PCR primers and probe:}

Primers and TaqMan probe targeting the $d n a G$ gene located internally to the macromolecular synthesis of the (MMS) operon were used to detect C. sakazakii.

\section{Primers of MMS opern of Cronobacter:}

MMS Forward: gggatattgtccctgaaacag

MMS Reverse: cgagaataagccgcgcatt

\section{Real-time PCR amplification:}

Real-time PCR was carried out in an ABI PRISM 7000 sequence real-time PCR system (Applied Biosystems, USA). Thermal cycling conditions were as follows: $50{ }^{\circ} \mathrm{C}$ for $2 \mathrm{~min}$., followed by $95{ }^{\circ} \mathrm{C}$ for $10 \mathrm{~min}$., $95{ }^{\circ} \mathrm{C}$ for $15 \mathrm{sec}$. ( 40 or 50 cycles) and 60 ${ }^{\circ} \mathrm{C}$ for $60 \mathrm{sec}$. The cycle threshold $(\mathrm{Ct})$ was calculated using ABI PRISM 7000 Sequence Detection System Software. Negative values or lack of amplification were considered for $\mathrm{Ct}$ values of $>40$.

\section{RESULTS}

Table 1: Incidence of Cronobacter isolates in the examined samples

\begin{tabular}{cccc}
\hline \multirow{2}{*}{ Samples } & \multicolumn{2}{c}{ Positive samples } \\
\cline { 3 - 4 } Domiati cheese & 50 & No. of examined samples & $\%$ \\
\hline Kareish cheese & 50 & 2 & 4 \\
\hline Total & 100 & 6 & 8 \\
\hline
\end{tabular}

Table 2: Incidence of different Cronobacter spp. in the examined samples

\begin{tabular}{|c|c|c|c|c|}
\hline Isolated & & & & \\
\hline \multirow[t]{2}{*}{ Cronobacter spp. } & \multicolumn{2}{|c|}{ Domiati cheese } & \multicolumn{2}{|c|}{ Kareish cheese } \\
\hline & No. & $\%$ & No. & $\%$ \\
\hline C. sakazakii & 2 & 4 & 3 & 6 \\
\hline C. malonaticus & - & - & 2 & 4 \\
\hline C. turicensis & - & - & 1 & 2 \\
\hline Total & 2 & 4 & 6 & 12 \\
\hline
\end{tabular}


Assiut Vet. Med. J. Vol. 60 No. 142 July 2014

Table 3: Frequency distribution of different Cronobacter spp. in the examined samples using conventional methods

\begin{tabular}{ccccc}
\hline \multirow{2}{*}{$\begin{array}{c}\text { Isolated } \\
\text { Cronobacter spp. }\end{array}$} & Domiati & \multicolumn{2}{c}{ Kareish } \\
\cline { 2 - 5 } & No./2 & $\%$ & No./6 & $\%$ \\
\hline C. sakazakii & 2 & 100 & 3 & 50 \\
\hline C. malonaticus & - & - & 2 & 33.33 \\
\hline C. turicensis & - & - & 1 & 16.67 \\
\hline
\end{tabular}

Table 4: Frequency percentage of $C$. sakazakii recovered from samples using real time PCR

\begin{tabular}{cccc}
\hline & $\begin{array}{c}\text { No. of tested } C . \\
\text { sakazakii }\end{array}$ & \multicolumn{2}{c}{ Positive strains by real time PCR } \\
\cline { 3 - 4 } & 2 & No. & $\%$ \\
\hline Domiati & 3 & 2 & 66.67 \\
\hline Kareish & 5 & 2 & 40 \\
\hline
\end{tabular}

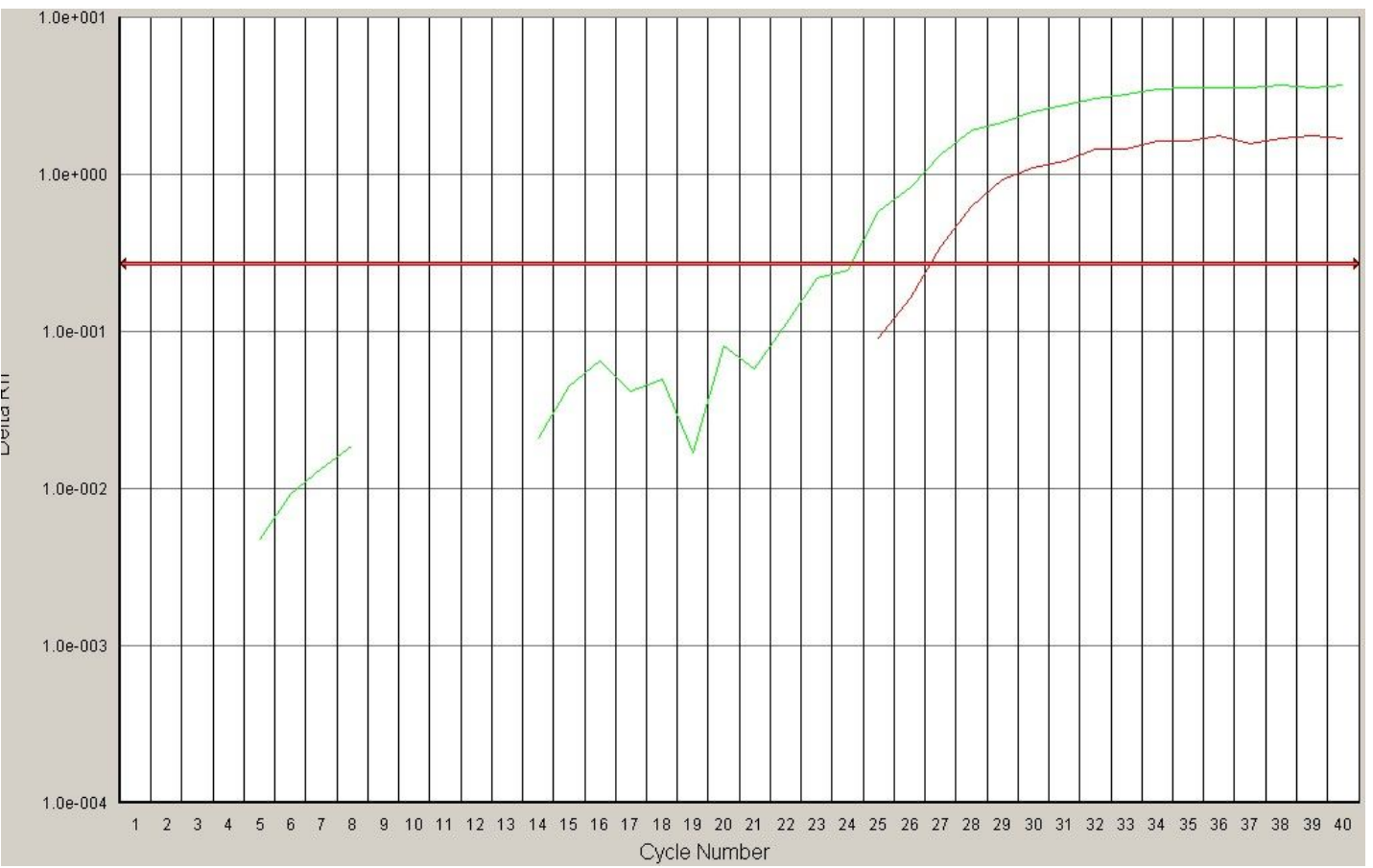

Photo 1: Results of real time PCR

Each of the amplified strains represented with a curve, curves cutted with a threshold line at a cycle number. When the number of the cycle is low, it indicates that this DNA is the target DNA of Cronobacter sakazakii. 


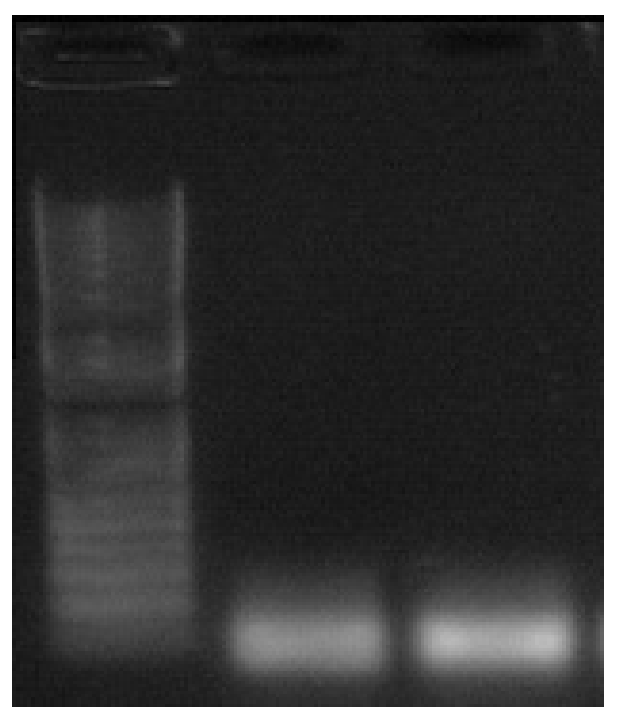

Photo 2: Results of real time PCR by gel electrophoresis using agarose gel stained with ethidium bromide.

\section{DISCUSSION}

Cronobacters have been detected in a wide range of environmental sources and from several foods of animal origin. Recent reports have identified Cronobacter infections inimmunocompromised adults. Therefore, this study focused on the detection of Cronobacter spp. in the most widely distributed and consumed types of cheese in Egypt. Results recorded in Table 1 according to the initial screening revealed that $2(4 \%)$ and $6(12 \%)$ of the examined Domiati and Kareish cheese samples were positive for Cronobacter spp., respectively with an overall incidence of $8(8 \%)$ of samples.

Results summarized in Table 2 showed that the isolated strains of Cronobacter spp. from Domiati cheese were identified as C. sakazakii (4\%), while those isolated from Kareish cheese were identified as C. sakazakii $(6 \%), \quad$ C. malonaticus $(4 \%)$ and C. turicensis $(2 \%)$. Table 3 showed the frequency distribution of different Cronobacter spp. in the examined samples using the conventional techniques. This association of the pathogen with cheese may be due to that the manufacture of kareish cheese is based on traditional method from raw milk without any regard to the hygienic quality of the product; moreover it is sold in markets without packing. Moreover, Gran et al. (2002) concluded that the hygienic aspects of dairy products are linked with transportation, preservation and handling.

Biochemical profiling of Cronobacter can be considered a first screening identification method after which the isolates should undergo further diagnostic analysis. So that, the isolates were subjected to Real-time PCR as a second step of identification.
Results recorded in Table 4 indicated that none of the 2 strains isolated from Domiati cheese were confirmed for the identity of $C$. sakazakii by real time PCR. Surprisingly, it is worth mentioning that 2 out of 3 tested strains isolated from kareish cheese were positive for $C$. sakazakii as shown in photos $1 \& 2$. The higher number of $C$. sakazaki obtained by conventional methods may be due to the close relation between $C$. sakazakii and $C$. malonaticus which cannot be differentiated using the conventional methods and easily differentiated by molecular techniques as real time PCR. From the aforementioned data, it could be concluded that real time PCR was accurate and reliable method for identification of Cronobacter species.

El-Sharoud et al. (2009) could not detect C. sakazakii in some cheese kinds including stored Domiati and Kareish cheese. On the other hand, the current findings were consolidated by Leclercq et al. (2002) as they isolated $C$. sakazakii from cheese and ElSharoud et al. (2009) who reported that C. sakazakii was isolated from fresh Domiati cheese samples (40\%). These results are in parallel with the findings of Gökmen et al. (2010) who pointed out that the presence of $C$. sakazakii in white cheese samples was 4\% (2/50), while, El-Gamal et al. (2013) could isolate this pathogen from Domiati cheese in a percentage of 30\%. Also, Zhao et al. (2013) detected the organism in the examined cheese samples.

From this study and literatures, this variation in results may be attributed to different processing and analysis techniques, in addition to that there was some sequence variability in the genes of the tested strains (Lehner et al., 2006).

The association of Cronobacters with cheese suggests 
that restrict precautions must be taken in its preparation, handling and storage.

\section{REFERENCES}

A.P.H.A. "American Public Health Association" (2004): Standard Methods for the Examination of Dairy Products, $17^{\text {th }}$ Ed., American Public Health Association, Washington, D.C.

El-Gamal, M.; Dairouty, R.K.; Okada, A.; Salah, S. and El-Shamy, S. (2013): Incidence and interrelation of Cronobacter sakazakii and other foodborne bacteria in some milk products and infant formula milks in Cairo and Giza area. World Appl. Sci. J., 26 (9): 1129-1141.

El-Sharoud, W.; El-Din, M.; Ziada, D.; Ahmed, S. and Klena, J. (2008): Surveillance and genotyping of Enterobacter sakazakii suggest its potential transmission from milk powder into imitation recombined soft cheese. J. Applied Microbiol., 105 (2): 559-566.

El-Sharoud, W.; O'Brien, S.; Negredo, S.; Iversen, C.; Fanning, $\quad S$. and Healy, B. (2009): Characterization of Cronobacter recovered from dried milk and related products. BMC Microbiol., 9: 24.

Farmer, J.; Asbury, M.; Hickman, F. and Brenner, D. (1980): Enterobacter sakazakii: A new species of "Enterobacteriaceae" isolated from clinical specimens. IJSEM, 30 (3): 569-584.

Friedemann, M. (2007): Enterobacter sakazakii in food and beverages (other than infant formula and milk powder). Int. J. Food Microbiol., 116 (1): 1-10.

Gökmen, M.; Tekinsen, K. and Gürbüz, U. (2010): Presence of Enterobacter sakazakii in milk powder, whey powder and white cheese produced in Konya. Kafkas Univ. Vet. Fak. Derg., 16: 163-166.

Gran, H.; Mutukumira, A.; Wetlesen, A. and Narvhus, $J$. (2002): Small holder dairy processing in Zimbabwe: the production of fermented milk products with particular emphasis on sanitation and microbiological quality. Food Control, 13 (3): 161-168.

Healy, B.; Cooney, S.; O'Brien, S.; Iversen, C.; Whyte, P.; Nally, J.; Callanan, J. and Fanning, S. (2010): Cronobacter (Enterobacter sakazakii): An opportunistic foodborne pathogen. Foodborne Pathogens and Disease, 7(4): 339-350.

Hunter, C.J. and Bean, J.F. (2013): Cronobacter: an emerging opportunistic pathogen associated with neonatal meningitis, sepsis and necrotizing enterocolitis. Journal of Perinatology, 33: 581-585.

Iversen, C.; Lehner, A.; Mullane, N.; Bidlas, E.; Cleenwreck, I.; Marugg, J.; Fanning, S.; Stephan, R. and Joosten, H. (2007): The taxonomy of Enterobacter sakazakii: proposal of a new genus Cronobacter gen. nov. and descriptions of Cronobacter sakazakii comb. nov. Cronobacter sakazakii subsp. sakazakii, comb. nov., Cronobacter sakazakii subsp. malonaticus subsp. nov., Cronobacter turicensis sp. nov., Cronobacter muytjensii sp. nov., Cronobacter dublinensis sp. nov. and Cronobacter genomospecies 1. BMC Evol. Biol., 7:64.

Iversen, C.; Mullane, N.; McCardell, B.; Tall, B.; Lehner, A.; Fanning, S.; Stephan, R. and Joosten, H. (2008): Cronobacter gen. nov., a new genus to accommodate the biogroups of Enterobacter sakazakii, and proposal of Cronobacter sakazakii gen. nov., comb. nov., Cronobacter malonaticus sp. nov., Cronobacter turicensis sp. nov., Cronobacter muytjensii sp. nov., Cronobacter dublinensis sp. nov., Cronobacter genomospecies 1, and of three subspecies, Cronobacter dublinensis subsp. dublinensis subsp. nov., Cronobacter dublinensis subsp. lausannensis subsp. nov. and Cronobacter dublinensis subsp. lactaridi subsp. nov. IJSEM, 58 (6), 1442-1447.

Joseph, S.; Sonbol, H.; Hariri, S.; Desai, P.; McClelland, M. and Forsythe, S. (2012): Diversity of the Cronobacter genus as revealed by multilocus sequence typing. J. Clinical Microbiol., 50 (9): 3031-3039.

Kucerova, E.; Joseph, S. and Forsythe, S. (2011): The Cronobacter genus: ubiquity and diversity. Quality Assurance and Safety of Crops \& Foods, 3, 104-122.

Leclercq, A.; Wanegue, C. and Baylac, P. (2002): Comparison of Fecal Coliform Agar and Violet Red Bile Lactose Agar for Fecal Coliform Enumeration in Foods. Appl. Environ. Microbiol., 68 (4): 1631-1638.

Lehner, A.; Nitzsche, S.; Breeuwer, P.; Diep, B.; Thelen, K. and Stephan, R. (2006): Comparison of two chromogenic media and evaluation of two molecular based identification systems for Enterobacter sakazakii detection. BMC Microbiol., 6, 15.

Nazarowec-White, M. and Farber, J.M. (1997): Enterobacter sakazakii: a review. Int. J. Food Microbiol., 34 (2): 103-113.

Seo, K.H. and Brackett, R.E. (2005): Rapid, specific detection of Enterobacter sakazakii in infant formula using a real-time PCR assay. J. Food Prot., 68 : 59-63.

Urmenyi, A.M.C. and Franklin, A.W. (1961): Neonatal death from pigmented coliform infection. Lancet 1: 313-315.

Zhao, Y.; Yao, Y.; Xiao, M.; Chen, Y.; Lee, C.; Zhang, L.; Zhang, K.; Yang, S. and Gu M. (2013): Rapid detection of Cronobacter sakazakii in dairy food by biofunctionalized magnetic nanoparticle based on nuclear magnetic resonance. Food Control, 34 (2): 436-443. 


\section{تواجد الكرونوباكتر فى الجبن القريش والامياطى \\ نجاح محمد سعد ، ولاء فاروق أمين \\ Email: wallaa 800@yahoo.com}

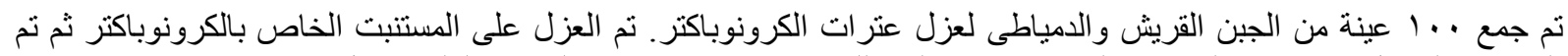

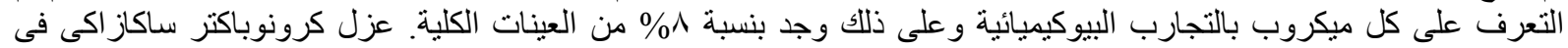

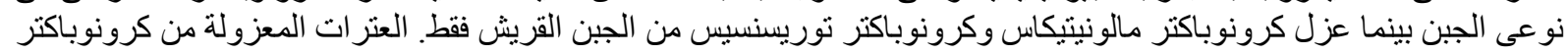

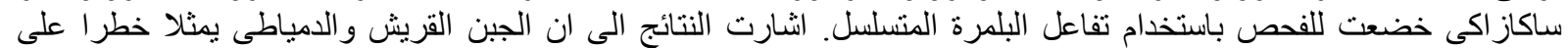
الانسان ويجب الانتباه اكثر لتصنيع ومعاملة هذه الاجبان. 